University of Nebraska - Lincoln

DigitalCommons@University of Nebraska - Lincoln

\title{
Alkaline iron(III) reduction by a novel alkaliphilic, halotolerant, Bacillus sp. isolated from salt flat sediments of Soap Lake
}

Jarrod Pollock

University of California, Berkeley, jarrod.pollock@grizmail.umt.edu

Karrie A. Weber

University of Nebraska-Lincoln, kweber@unl.edu

Joe Lack

Southern Illinois University Carbondale

Laurie A. Achenbach

Southern Illinois University Carbondale, laurie@micro.siu.edu

Melanie R. Mormile

University of Missouri, Rolla

See next page for additional authors

Follow this and additional works at: https://digitalcommons.unl.edu/bioscifacpub

Part of the Life Sciences Commons

Pollock, Jarrod; Weber, Karrie A.; Lack, Joe; Achenbach, Laurie A.; Mormile, Melanie R.; and Coates, John D., "Alkaline iron(III) reduction by a novel alkaliphilic, halotolerant, Bacillus sp. isolated from salt flat sediments of Soap Lake" (2007). Faculty Publications in the Biological Sciences. 205.

https://digitalcommons.unl.edu/bioscifacpub/205

This Article is brought to you for free and open access by the Papers in the Biological Sciences at DigitalCommons@University of Nebraska - Lincoln. It has been accepted for inclusion in Faculty Publications in the Biological Sciences by an authorized administrator of DigitalCommons@University of Nebraska - Lincoln. 


\section{Authors}

Jarrod Pollock, Karrie A. Weber, Joe Lack, Laurie A. Achenbach, Melanie R. Mormile, and John D. Coates 


\title{
Alkaline iron(III) reduction by a novel alkaliphilic, halotolerant, Bacillus sp. isolated from salt flat sediments of Soap Lake
}

\author{
Jarrod Pollock, ${ }^{1,4}$ Karrie A. Weber, ${ }^{1}$ Joe Lack, ${ }^{2}$ Laurie A. Achenbach, ${ }^{2}$ \\ Melanie R. Mormile, ${ }^{3}$ and John D. Coates ${ }^{1}$ \\ 1. University of California, Berkeley, CA 94720, USA \\ 2. Southern Illinois University, Carbondale, IL, USA \\ 3. University of Missouri, Rolla, MO, USA \\ 4. Present address: University of Montana, Missoula, MT, USA \\ Corresponding author - John D. Coates, email jcoates@nature.berkeley.edu
}

\begin{abstract}
A halotolerant, alkaliphilic dissimilatory Fe(III)-reducing bacterium, strain SFB, was isolated from salt flat sediments collected from Soap Lake, WA. 16S ribosomal ribonucleic acid gene sequence analysis identified strain SFB as a novel Bacillus sp. most similar to Bacillus agaradhaerens (96.7\% similarity). Strain SFB, a fermentative, facultative anaerobe, fermented various hexoses including glucose and fructose. The fructose fermentation products were lactate, acetate, and formate. Under fructose-fermenting conditions in a medium amended with $\mathrm{Fe}(\mathrm{III}), \mathrm{Fe}(\mathrm{II})$ accumulated concomitant with a stoichiometric decrease in lactate and an increase in acetate and $\mathrm{CO}_{2}$. Strain SFB was also capable of respiratory Fe(III) reduction with some unidentified component(s) of Luria broth as an electron donor. In addition to $\mathrm{Fe}(\mathrm{III})$, strain SFB could also utilize nitrate, fumarate, or $\mathrm{O}_{2}$ as alternative electron acceptors. Optimum growth was observed at $30^{\circ} \mathrm{C}$ and $\mathrm{pH}$. Although the optimal salinity for growth was $0 \%$, strain SFB could grow in a medium with up to $15 \% \mathrm{NaCl}$ by mass. These studies describe a novel alkaliphilic, halotolerant organism capable of dissimilatory Fe(III) reduction under extreme conditions and demonstrate that Bacillus species can contribute to the microbial reduction of Fe(III) in environments at elevated $\mathrm{pH}$ and salinity, such as soda lakes.
\end{abstract}

Keywords: Dissimilatory Fe(III) reduction, Bacillus, Extremeophile, Alkaliphile, Halotolerant

\section{Introduction}

Soda lakes and soda deserts represent naturally occurring alkaline environments enriched in chloride and carbonate with stable, extremely high $\mathrm{pH}$ values often exceeding 11.5 (Jones et al. 1998). Autochthonous photosynthetic primary productivity by cyanobacteria is the principal carbon input into these ecosystems (Jones et al. 1998 and references therein). Soda lakes are extremely biologically productive, with extensive anoxic zones developing implicating the potential role of anaerobic metabolic processes in these environments (Jones et al. 1998 and references therein). As such, these naturally alka- line environments support a diversity of aerobic and anaerobic microorganisms (Duckworth et al. 1996; Jones et al. 1998; Ma et al. 2004). Given that iron is the fourth most abundant element in the earth's crust (Cornell and Schwertmann 2003), it is likely that sediments within alkaline environments such as soda lakes can support iron-reducing microorganisms.

Microbially mediated iron reduction is a well-recognized, ubiquitous environmental process, consequently influencing the degradation of organic matter as well as soil and sediment geochemistry (Weber et al. 2006 and references therein). A variety of Fe(III)-reducing organisms have been isolated and described from a broad di- 
versity of environments that displayed a vast array of chemical and physical conditions (Weber et al. 2006). From among these isolated microorganisms, Fe(III)reducing extremophiles representing hyperthermophilic, thermophilic, psychrophilic, acidophilic, and alkaliphilic Archaea and Bacteria have been described in pure culture (Bowman et al. 1997; Kusel et al. 1999; Roh et al. 2002; Kashefi and Lovley 2003; Lovley et al. 2004 and references therein). Alkaliphilic bacteria capable of $\mathrm{Fe}(\mathrm{III})$ reduction have been isolated from natural alkaline environments such as Mono Lake (Blum et al. 1998; Gorlenko et al. 2004) as well as anthropogenic industrial borate leachate ponds (Ye et al. 2004). Before the recent isolation of Alkaliphilus metalliredigens strain QYMF (Ye et al. 2004) and Anaerobranca californiensis (Gorlenko et al. 2004), Fe(III) reduction had not been observed beyond a $\mathrm{pH}$ of 9.0 (Boone et al. 1995; Blum et al. 1998; Kanso et al. 2002). Identification of these alkaliphilic microorganisms expanded the upper $\mathrm{pH}$ limit to $\mathrm{pH} 10.4$ in which microbial Fe(III) reduction was recognized to occur. In addition, identification of these microorganisms also implicates the probable contribution of microbially mediated $\mathrm{Fe}(\mathrm{III})$ reduction as a component of the iron redox cycle within alkaline environments. Thus, microbially mediated iron redox cycling in natural alkaline environments could not only significantly contribute to the mineralization of organic matter but also the formation of reduced iron minerals in these environments.

To investigate the potential for dissimilatory iron reduction in a natural alkaline, saline environment, a series of $\mathrm{Fe}(\mathrm{III})$-reducing enrichments were initiated from an alkaline salt flat of Soap Lake, a soda lake containing basalt, an iron-rich mineral, located in Grant County, WA. In this paper, we describe strain SFB, a bacterium capable of Fe(III) reduction at $\mathrm{pH}$ levels as high as 11.0 and salinity of $12.5 \%$. Based on the complete $16 \mathrm{~S}$ rRNA genomic sequence, strain SFB was identified as a Bacillus species.

\section{Materials and methods}

Source of sediments, enrichment, and isolation

Unsaturated salt flat sediments were collected from Soap Lake (WA), an alkaline, saline soda lake. Primary enrichments selective for alkaliphilic, halophilic, iron-reducing microorganisms were initiated in anaerobic culture tubes (Bellco Biotechnology product no. 2048-18150) containing medium A (described below) amended with yeast extract, $\mathrm{Fe}(\mathrm{III})$-citrate, and glycerol with the sediment slurry and incubated at room temperature in the dark. Ferric citrate was added from an anoxic (100\% $\mathrm{N}_{2}$ atmosphere) stock solution prepared by the dissolution of ferric citrate monohydrate as previously described (Lovley and Phillips 1988). Enrich- ments positive for iron reduction were qualitatively determined by the change in color of the aqueous solution from reddish-brown to clear. The primary enrichments were then successively transferred an additional three times before serial dilution in medium $\mathrm{A}$, noble agar ( $2 \%$ final concentration) shake tubes as previously described (Bruce et al. 1999). After approximately 1 month of incubation, colonies that developed in the most dilute noble agar shake tubes were isolated in an anaerobic glove bag $\left(95: 5, \mathrm{~N}_{2} / \mathrm{H}_{2}\right)$ using aseptic techniques and transferred into medium $\mathrm{A}$.

\section{Media and culturing techniques}

Medium A contained the following (per $990 \mathrm{~mL}$ distilled deionized [ddi] $\left.\mathrm{H}_{2} \mathrm{O}\right): \mathrm{NaCl}(125 \mathrm{~g}), \mathrm{NaH}_{2} \mathrm{PO}_{4} \cdot 2 \mathrm{H}_{2} \mathrm{O}$ $(0.5 \mathrm{~g}), \mathrm{NH}_{4} \mathrm{Cl}(1.0 \mathrm{~g})$, yeast extract $(2.0 \mathrm{~g}), \mathrm{Na}_{2} \mathrm{~B}_{4} \mathrm{O}_{7}$ $(4.0 \mathrm{~g}), \mathrm{Fe}(\mathrm{III})$ citrate $(12 \mathrm{~g}), 10 \mathrm{~mL}$ of $100 \%$ glycerol, vitamins, and trace minerals as previously described (Bruce et al. 1999). The $\mathrm{pH}$ was adjusted to achieve a final $\mathrm{pH}$ of 9.0. Subsequent to isolation, strain SFB was transferred into a defined medium, denoted as medium $\mathrm{B}$. Medium $\mathrm{B}$ contained the following (per liter ddi $\mathrm{H}_{2} \mathrm{O}$ ): $\mathrm{NaCl}(125 \mathrm{~g}), \mathrm{NH}_{4} \mathrm{Cl}(0.25 \mathrm{~g}), \mathrm{NaH}_{2} \mathrm{PO}_{4}(0.4 \mathrm{~g}), \mathrm{Na}_{2} \mathrm{~B}_{4} \mathrm{O}_{7}$ $(4 \mathrm{~g})$, vitamins, and trace minerals as previously described (Bruce et al. 1999). The $\mathrm{pH}$ was adjusted to obtain the final $\mathrm{pH}$ of 9.0.

Preparation of anoxic media was achieved by heating the culture medium to $100^{\circ} \mathrm{C}$ under a constant $100 \% \mathrm{~N}_{2}$ headspace. Culture media was then cooled to room temperature under a $100 \% \mathrm{~N}_{2}$ headspace and subsequently dispensed under an anoxic atmosphere $\left(100 \% \mathrm{~N}_{2}\right.$ headspace) into anaerobic culture tubes sealed with thick butyl rubber stoppers (Bellco Biotechnology product no. 2048-18150), crimped, and autoclaved $\left(20 \mathrm{~min}\right.$ at $\left.121^{\circ} \mathrm{C}\right)$. Anaerobic microbiological culture techniques were employed as described previously by Hungate (1969).

\section{Alternative electron donors and acceptors}

Growth substrates including alternative electron donors and acceptors were added to medium B from sterile, anoxic (100\% $\mathrm{N}_{2}$ atmosphere) aqueous stocks. Luria broth (LB, Difco no. 240230) was added from an anoxic, sterile concentrated stock solution to yield a final concentration of $0.25 \%$. Fe(III) was supplied in the form of soluble $\mathrm{Fe}(\mathrm{III})$ complexes; however, upon addition to the basic culture medium ( $\mathrm{pH}>9.0)$, approximately $12 \%$ of the Fe(III) precipitated as a solid phase. Fe(III) citrate (50 mM; Lovley and Phillips 1988), Fe(III) chelated with nitrilotriacetic acid (Fe(III)-NTA) (10 mM; Roden and Lovley 1993), or Fe(III) pyrophosphate (10 mM; Caccavo et al. 1994; Coates et al. 1996) served as the Fe(III) sources. $\mathrm{Mn}(\mathrm{IV})$ was supplied as synthetic $\mathrm{MnO}_{2}$ that was prepared as previously described (Lovley and Phillips 1988) to give a final concentration of $10-30 \mathrm{mmol}$ 
$\mathrm{L}^{-1}$. All other electron acceptors were prepared as anoxic aqueous stocks of the sodium salts to give final medium concentrations of $10 \mathrm{mM}$ unless otherwise stated.

Analytical techniques

HCl-extractable $(0.5 \mathrm{~N}) \mathrm{Fe}(\mathrm{II})$ and total iron were determined using the colorimetric Ferrozine assay as previously described (Lovley and Phillips 1988). Acetate, formate, and lactate concentrations were analyzed by high-performance liquid chromatography (HPLC) with UV detection at $210 \mathrm{~nm}$ (Shimadzu SPD-10A) using a HL-75H+ cation exchange column (Hamilton no. 79476) with a $\mathrm{H}_{2} \mathrm{SO}_{4}(0.016 \mathrm{~N})$ eluent at a flow rate of $0.4 \mathrm{~mL} \mathrm{~min}^{-1}$ (Bruce et al. 1999). Aqueous samples for HPLC analysis were filtered with the OnGuard-Ag (DIONEX Cat no. P/N 39637) chromatography filter to remove excess chloride ions. Cell density was monitored by direct microscopic cell counts (Petroff-Hausser Counter, $0.02 \mathrm{~mm}$ depth) under oil immersion at $100 \times$ magnification.

\section{Sequence analysis of the $16 \mathrm{~S}$ rRNA gene}

Bacterial genomic deoxyribonucleic acid (DNA) from pure culture samples was obtained using the FastDNA SPIN Kit for Soil (BIO 101). Amplification, sequencing, and phylogenetic analysis of the 165 ribosomal DNA (rDNA) was performed as previously described (Coates et al. 1999). The complete $16 \mathrm{~S}$ ribosomal ribonucleic acid gene sequence from strain SFB was deposited in GenBank under accession number AY669375.

\section{Results}

\section{Enrichment and isolation}

Ferric iron-reducing enrichments initiated from salt flat sediment slurries collected from Soap Lake, Grant County, WA, were successfully transferred before isolation. Fe(III) reduction was observed in the transfer after 5 days as determined by visual observation of the brown-colored $\mathrm{Fe}(\mathrm{III})$ citrate medium turning colorless with a small white precipitate in the bottom of the tube. The enrichment was transferred three more times over the following 3 weeks before serial dilution into agar tubes. Small colonies were apparent after 5 weeks of incubation. The visible colonies ranged from 1 to $4 \mathrm{~mm}$ in diameter and were white or pink in color. In the lower dilution tubes, all colonies were pink in color and were surrounded by a colorless halo indicative of Fe(III) reduction. Several of these were selected for isolation from the agar dilution series and were transferred into fresh medium $\mathrm{A}$ and incubated at $30^{\circ} \mathrm{C}$. One pure culture, strain SFB, that demonstrated Fe(III) reduction af- ter 1 month of incubation was selected from among the morphologically similar isolates obtained for further characterization and maintained on medium B with lactate and $\mathrm{Fe}(\mathrm{III})$ citrate.

\section{Cell morphology}

Cells of strain SFB were 8 by $0.5 \mu \mathrm{m}$, Gram positive, and motile (Figure 1). Colonies developed during anaerobic growth on Fe(III) citrate-amended medium A solidified with $1.2 \%$ agar were small ( 0.5 to $1 \mathrm{~mm}$ diameter) and white in color surrounded by a colorless halo where the $\mathrm{Fe}(\mathrm{III})$ had been reduced. Spores were not visible in wet mounts by phase contrast microscopy under oil immersion at $100 \times$ magnification; however, spore formation was indicated, as growth of strain SFB was observed subsequent to pasteurization at $80^{\circ} \mathrm{C}$ for $10 \mathrm{~min}$ (data not shown).

\section{Phylogenetic analysis}

Comparative phylogenetic analysis of the complete $16 \mathrm{~S}$ rRNA gene sequence placed strain SFB as a member of the Bacillus genus in the phylum Firmicutes (Figure 2). The closest $16 \mathrm{~S}$ rRNA gene sequence match (98.1\% sequence similarity) in nucleotide databases was a clonal isolate identified in a bacterial community from a soda lake in Hungary (Genbank accession number AM051264, unpublished). The closest known cultured relative was an alkaliphilic Bacillus sp., B. agaradhaerens (Nielsen et al. 1994; Nielsen et al. 1995; Blum et al. 1998),

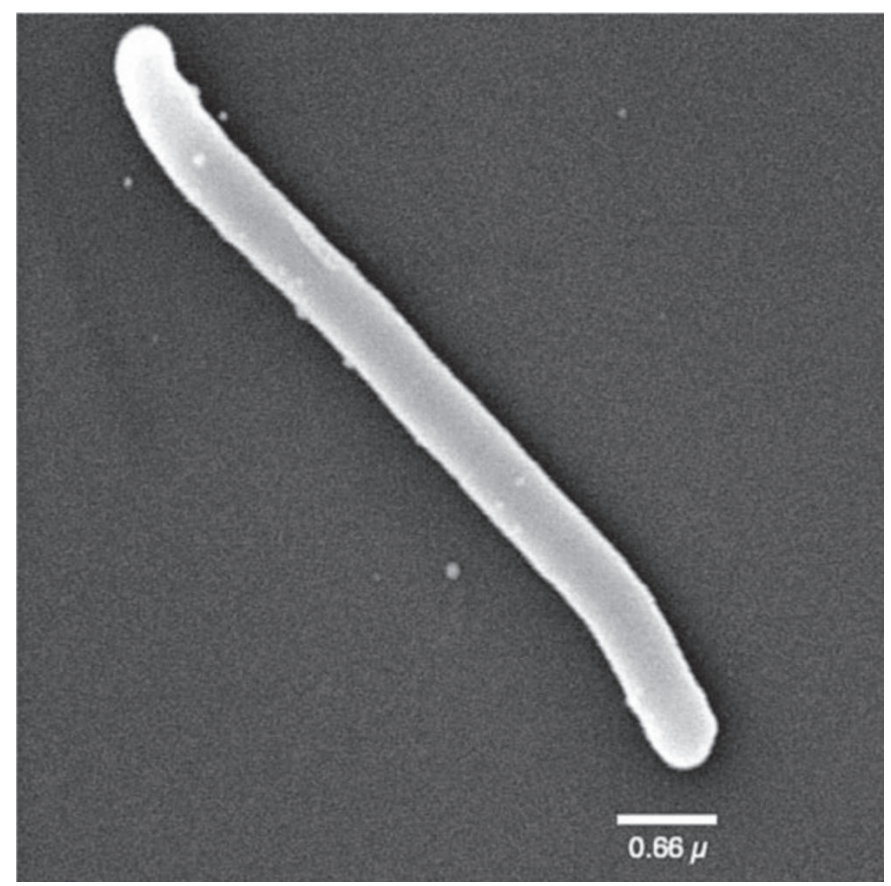

Figure 1. Scanning electron micrograph of Bacillus sp. strain SFB. 


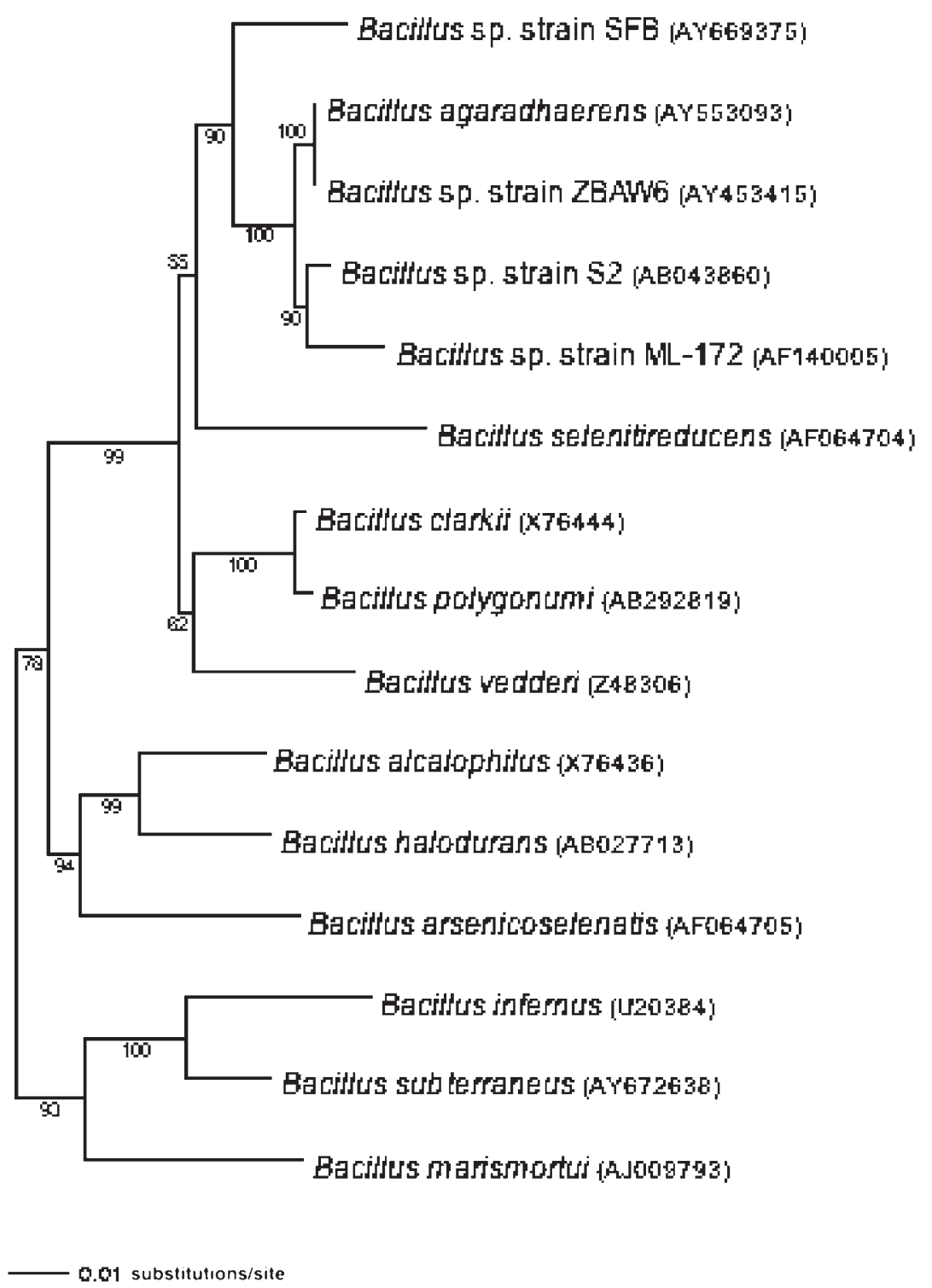

Figure 2. Unrooted phylogenetic tree of the complete $16 \mathrm{~S}$ rDNA sequence of Bacillus sp. strain SFB dataset resulting from distance analysis using a heuristic search with the Kimura two-parameter correction. The same topology was obtained using either parsimony or maximum likelihood and was based on 1,311 sequence characters. Results from bootstrap analysis of 100 replicates are indicated.

with $96.7 \% 16 \mathrm{~S}$ rDNA sequence identity with strain SFB over 1,469 aligned nucleotide positions. Only three other Bacillus species, B. infernus, B. subterraneus, and B. arsenicoselenatis, have demonstrated metabolic Fe(III) reduction at elevated $\mathrm{pH}$ and salinity. Of these three organisms, only B. arsenicoselenatis has been identified as an alkaliphilic Fe(III)-reducing bacterium.

Optimal growth and iron-reducing conditions

Physiological characterization revealed that strain SFB was a robust organism capable of growth over a broad variety of environmental conditions. Strain SFB demonstrated tolerance to an extreme salinity range of $0-15 \%$, although optimal growth and Fe(III) reduction was observed when $\mathrm{NaCl}$ was omitted from culture media (Figure 3a). Similarly, growth and Fe(III) reduction were observed over a broad spectrum of temperature (23 to $40^{\circ} \mathrm{C}$; Figure $3 \mathrm{a}$ ) and $\mathrm{pH}$ values ( $\mathrm{pH} 8.5$ to 11 ; Figure $3 \mathrm{~b}$ ). Optimal growth was observed at $30^{\circ} \mathrm{C}$ and $\mathrm{pH} 9$.

Respiratory Fe(III) reduction

The accumulation of $\mathrm{Fe}(\mathrm{II})$, indicative of $\mathrm{Fe}(\mathrm{III})$ reduction, was observed concurrent with an increase in biomass when strain SFB was cultured in anoxic basal media containing lactate as the primary electron donor amended with LB and Fe(III), added as Fe(III)-NTA, as 

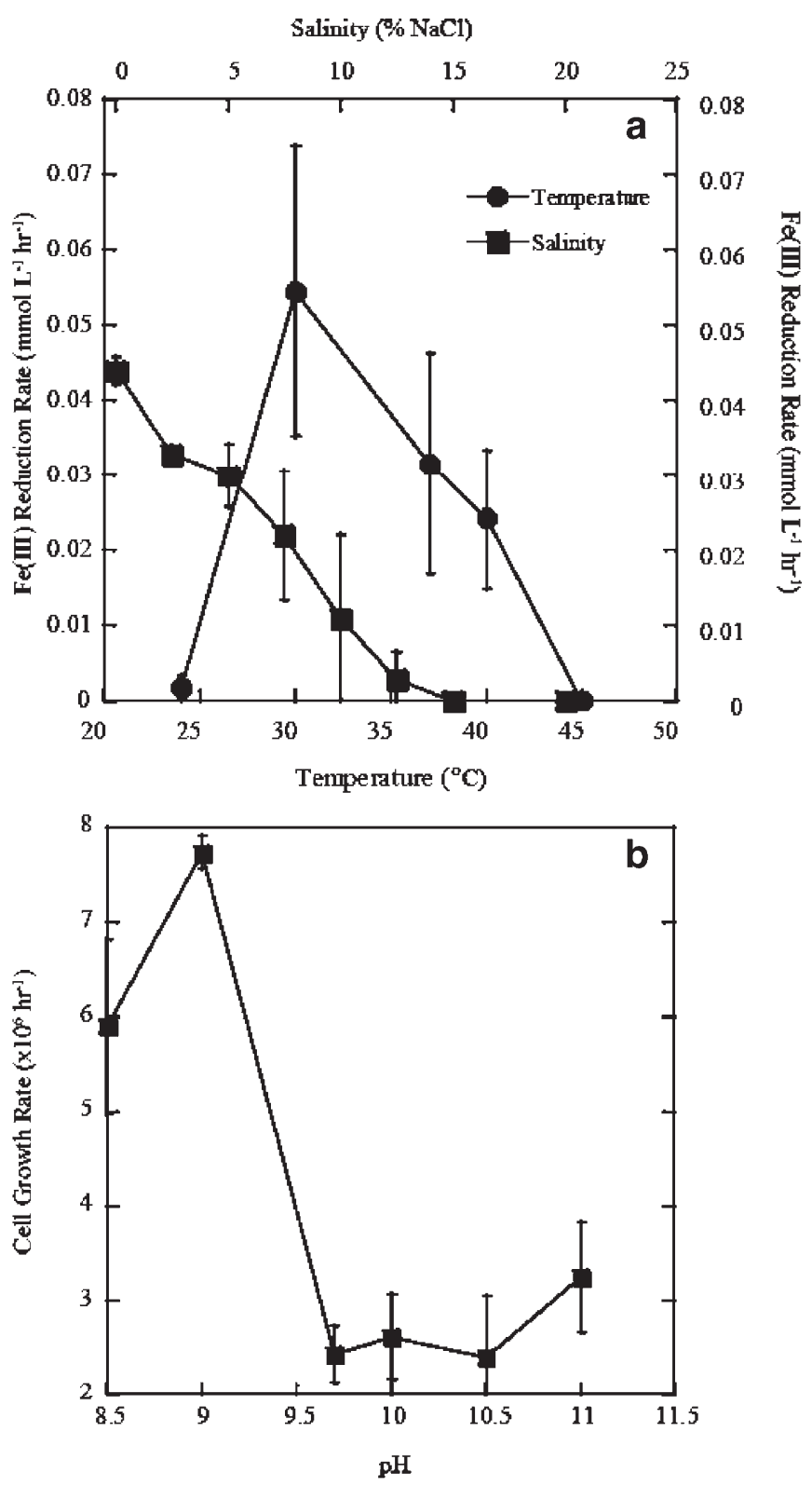

Figure 3. The effect of salinity and temperature (a) and $\mathrm{pH}$ (b) on the rate of $\mathrm{Fe}(\mathrm{III})$ reduction and growth by Bacillus sp. strain SFB. Symbols denote average of triplicate samples. Error bars represent standard error of measure.

the sole electron acceptor (Figure 4). Upon addition of $10 \mathrm{mM}$ Fe(III)-NTA to the alkaline basal culture medium $12 \%$ of the Fe(III) content precipitated as a solid phase. Reduction the solid-phase Fe(III) in the culture medium suggests that strain SFB may also be capable of reducing solid-phase Fe(III). Cell growth and Fe(III) reduction were also observed in control cultures from which the lactate was omitted (data not shown) suggesting that the growth and $\mathrm{Fe}(\mathrm{III})$ reduction were dependent on the $\mathrm{LB}$ as the electron donor. In the absence of LB, neither $\mathrm{Fe}(\mathrm{III})$ reduction nor an increase in cell biomass was observed (Figure 4). Similarly, no significant cell increase

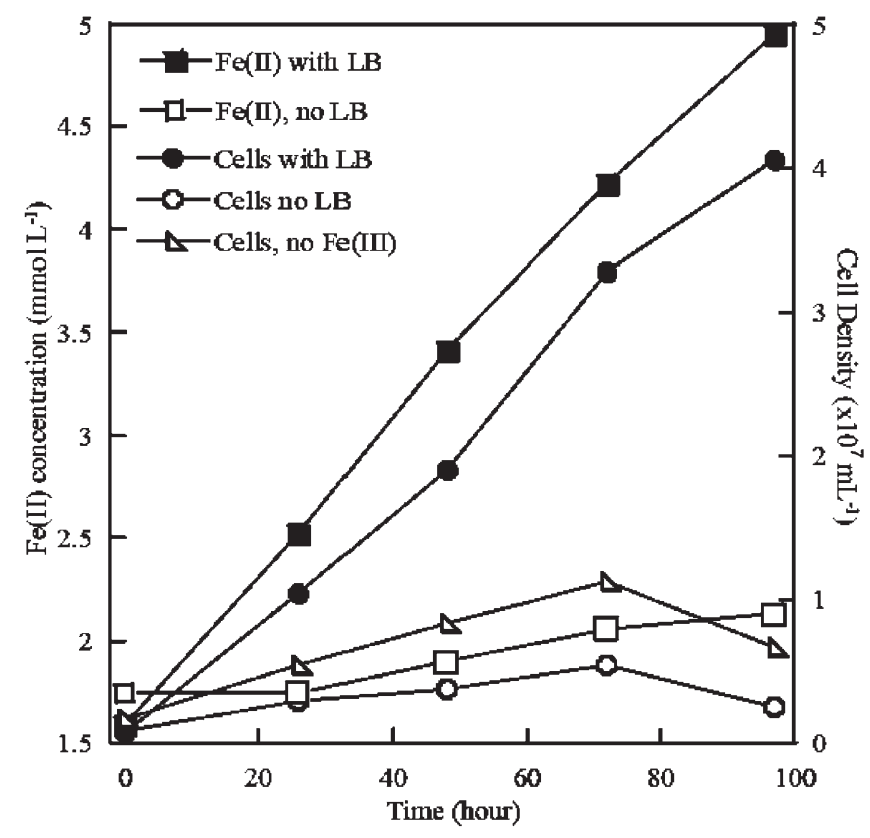

Figure 4. Respiratory growth of Bacillus sp. strain SFB on media in the presence of LB and Fe(III)-NTA (filled circles), Fe(III)NTA, no LB (open circles), LB with no Fe(III)-NTA (open triangles) and dissimilatory $\mathrm{Fe}(\mathrm{III})$ reduction with $\mathrm{LB}$ and $\mathrm{Fe}(\mathrm{III})-\mathrm{NTA}$ (filled squares), and Fe(III)-NTA with no LB (open squares). Symbols denote average of triplicate samples.

was observed in the absence of the Fe(III) (Figure 4) indicating that growth of strain SFB was dependent on the oxidation of some unidentified component(s) of LB coupled to the respiratory reduction of Fe(III).

Fermentative Fe(III) reduction

In addition to the utilization of LB as a growth substrate during respiratory $\mathrm{Fe}(\mathrm{III})$ reduction, strain SFB was also capable of fermentation of a variety of sugars (Table 1). Cell growth occurred in an anoxic basal medium amended with fructose $(1 \mathrm{mM})$ as the sole carbon and energy source in the absence of alternative electron acceptors (Figure 5a). Fructose was fermented primarily to lactate, formate, and acetate by strain SFB. A carbon balance resulted in the recovery of $103 \%$ (Table 2) of carbon with a molar ratio of approximately 3:1:1 for the lactate, formate, and acetate, respectively. This is in close agreement with the balanced theoretical fermentation reaction:

$$
\begin{aligned}
& \mathrm{C}_{6} \mathrm{H}_{12} \mathrm{O}_{6}+2.5 \mathrm{OH}^{-} \rightarrow 1.5 \mathrm{C}_{3} \mathrm{H}_{5} \mathrm{O}_{3}^{-}+0.5 \mathrm{C}_{2} \mathrm{H}_{3} \mathrm{O}_{2}^{-} \\
& +0.5 \mathrm{HCO}_{2}^{-}+0.5 \mathrm{H}_{2}+3 \mathrm{H}_{2} \mathrm{O} \\
& \Delta G_{\mathrm{R}}{ }^{\prime \prime}=-452.7\left(\mathrm{~kJ} \mathrm{~mol}^{-1}\right)
\end{aligned}
$$

Although $\mathrm{H}_{2}$ headspace gas was not followed over the course of the experiment, $\mathrm{H}_{2}$ was also a likely product of fermentation based on the balanced fermentation equation. 
Table 1. Electron donors and accepters tested and utilized by strain SFB

\begin{tabular}{lll}
\hline & Utilized & Not utilized \\
\hline Electron donors & Glucose $(10 \mathrm{mM})$ & Hydrogen $(101 \mathrm{kPa})$ \\
& Sucrose $(10 \mathrm{mM})$ & Formate $(10 \mathrm{mM})$ \\
& Fructose $(10 \mathrm{mM})$ & Acetate $(10 \mathrm{mM})$ \\
& Lactose $(10 \mathrm{mM})$ & Propionate $(5 \mathrm{mM})$ \\
& Casamino acids $\left(1 \mathrm{~g} \mathrm{~L}^{-1}\right)$ & Butyrate $(5 \mathrm{mM})$ \\
& Yeast extract $\left(1 \mathrm{~g} \mathrm{~L}^{-1}\right)$ & Fumarate $(5 \mathrm{mM})$ \\
& Luria broth $\left(1 \mathrm{~g} \mathrm{~L}^{-1}\right)$ & Malate $(10 \mathrm{mM})$ \\
& Lactate $(10 \mathrm{mM})$ & Citrate $(10 \mathrm{mM})$ \\
& Formate $(10 \mathrm{mM})$ & \\
& Ethanol $(10 \mathrm{mM})$ & \\
Electron acceptors & Oxygen $(101 \mathrm{kPa})$ & Perchlorate $(5 \mathrm{mM})$ \\
& Fe(III)NTA $(10 \mathrm{mM})$ & Chlorate $(10 \mathrm{mM})$ \\
& Fe(III) Pyrophosphate & Sulfate $(10 \mathrm{mM})$ \\
& $(10 \mathrm{mM})$ & \\
Fe(III) Citrate $(10 \mathrm{mM})$ & \\
Fumarate $(10 \mathrm{mM})$ & \\
Nitrate $(10 \mathrm{mM})$ & \\
& & \\
\hline
\end{tabular}

Addition of $\mathrm{Fe}(\mathrm{III})$, as $\mathrm{Fe}(\mathrm{III})-\mathrm{NTA}$, to fructose fermentation cultures resulted in the reduction of the $\mathrm{Fe}(\mathrm{III})$ after 11 days (Figure $5 \mathrm{~b}$ ). Fe(III) reduction did not occur in cultures from which fructose or strain SFB was omitted (Figure 5b). In cultures amended with Fe(III), a transient accumulation of lactate was observed (data not shown). An increase in acetate with concomitant Fe(III) reduction occurred during the depletion of the accumulated lactate (data not shown). In contrast, omission of $\mathrm{Fe}(\mathrm{III})$ resulted in the continual increase in lactate with no additional acetate formation (data not shown). The molar ratio of lactate oxidized to Fe(III) reduced (0.23) occurred in close agreement with theoretical stoichiometry (0.25) according to:

$$
\begin{aligned}
& 1.5 \mathrm{C}_{3} \mathrm{H}_{5} \mathrm{O}_{3}^{-}+9 \mathrm{OH}^{-}+6 \mathrm{Fe}(\mathrm{III}) \\
& \rightarrow 1.5 \mathrm{C}_{2} \mathrm{H}_{3} \mathrm{O}_{2}^{-}+1.5 \mathrm{CO}_{3}{ }^{2-}+6 \mathrm{Fe}(\mathrm{II})+6 \mathrm{H}_{2} \mathrm{O} \\
& \Delta \mathrm{G}_{\mathrm{R}}{ }^{\prime \prime}=-863.7\left(\mathrm{~kJ} \mathrm{~mol}^{-1}\right)
\end{aligned}
$$

Together with the results reported above, the fermentation of fructose $(1 \mathrm{mM})$ should result in the formation of $1.5 \mathrm{mM}$ lactate, with a subsequent reduction of $6 \mathrm{mM}$ Fe(III) according to:

$$
\begin{aligned}
& \mathrm{C}_{6} \mathrm{H}_{12} \mathrm{O}_{6}+ 11.5 \mathrm{OH}^{-}+6 \mathrm{Fe}(\mathrm{III}) \\
& \rightarrow 2 \mathrm{C}_{2} \mathrm{H}_{3} \mathrm{O}_{2}^{-}+0.5 \mathrm{HCO}_{2}^{-}+0.5 \mathrm{H}_{2}+9 \mathrm{H}_{2} \mathrm{O} \\
&+1.5 \mathrm{CO}_{3}^{2-}+6 \mathrm{Fe}(\mathrm{II}) \\
& \Delta G_{\mathrm{R}}^{0 \prime}=-1,126.0\left(\mathrm{~kJ} \mathrm{~mol}^{-1}\right)
\end{aligned}
$$

The data presented are in agreement with theoretical calculations (97.5\%). Growth of strain SFB was observed concurrent with fructose fermentation (Figure 5a);

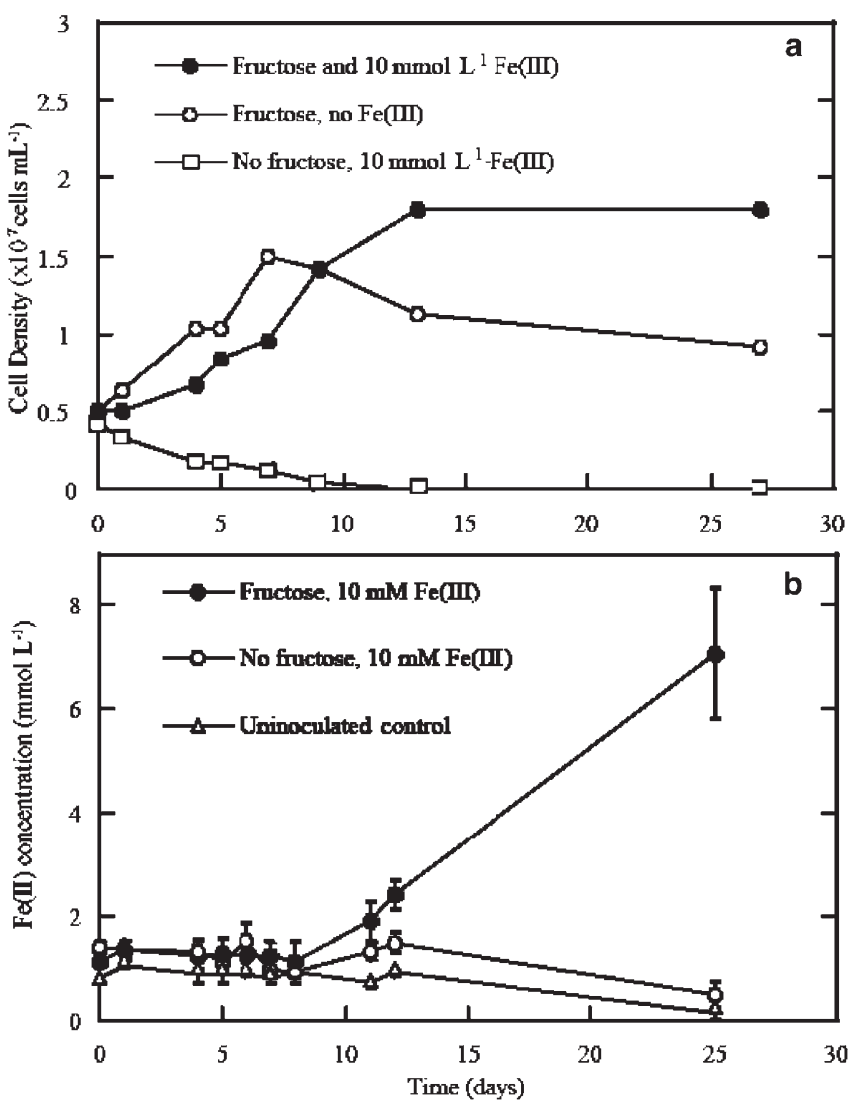

Figure 5. Growth (a) and Fe(III) reduction (b) by Bacillus sp. strain SFB in the presence and absence of Fe(III)-NTA (10 mM) as an electron acceptor during fructose $(1 \mathrm{mM})$ fermentation. Fructose only (open circles), fructose and Fe(III)-NTA (filled circles), Fe(III)-NTA only (open squares), and uninoculated (open triangles). Symbols denote average of triplicate samples.

however, cell growth did not continue during Fe(III) reduction. It is interesting to note that biomass did not decrease throughout the extended stationary phase of Fe(III)-amended cultures (Figure 5a).

Alternative electron donors and acceptors

In addition to fructose and some component(s) of LB, strain SFB was also capable of reducing Fe(III) with a variety of alternative carbon sources including sucrose, lactose, casamino acids, yeast extract, and lactate

Table 2. Carbon balance of the anaerobic fermentation products of $1 \mathrm{mM}$ fructose by Bacillus sp. strain SFB

\begin{tabular}{lll}
\hline Products & Yield $(\mu \mathrm{M})$ & Percent recovery $^{\mathrm{a}}$ \\
\hline Lactate & 1,490 & 74.5 \\
Formate & 540 & 9.0 \\
Acetate & 600 & 20.0 \\
\hline
\end{tabular}

a. Percent recovery is determined by moles carbon of product yield divided by the moles of carbon in fructose multiplied by 100 . 
(Table 1). With glucose $(10 \mathrm{mM})$ serving as the carbon and energy source, strain SFB could reduce molecular oxygen, nitrate, or fumarate (Table 1). It is interesting to note that although strain SFB did grow by fermentation of glucose, no $\mathrm{Fe}(\mathrm{III})$ reduction was observed when $\mathrm{Fe}(\mathrm{III})$ was added to the culture medium (data not shown). Under fumarate-reducing conditions, strain SFB was capable of respiratory growth, and succinate was formed as a product of fumarate reduction (data not shown). Fumarate was not utilized when supplied as an electron donor. In addition to Fe(III)NTA, Fe(III) citrate and Fe(III) pyrophosphate were also reduced during the fermentation of fructose (data not shown). A variety of potential alternative electron acceptors were also tested but not utilized by strain SFB (Table 1).

\section{Discussion}

$\mathrm{Fe}(\mathrm{III})$ reduction by alkaliphilic bacteria has only recently demonstrated with $B$. arsenicoselenatis, A. metalliredigens strain QYMF, and Anaerobranca sp. (Blum et al. 1998; Gorlenko et al. 2004; Ye et al. 2004) in pH as high as 10.4. Fe(III) reduction tested between a $\mathrm{pH}$ range of 8.5 and 11.0 resulted in the growth of strain SFB, with an optimal $\mathrm{pH}$ of 9.0. Strain SFB is a halotolerant bacterium capable of reducing $\mathrm{Fe}(\mathrm{III})$ at a salinity as high as $12.5 \%$. Distinct from the previously identified alkaliphilic, dissimilatory metal-reducing bacteria, strain SFB was identified as an alkaliphilic, halotolerant $B a-$ cillus sp. capable of respiratory and fermentative Fe(III) reduction at $\mathrm{pH}$ of 11.0 and salinity of $12.5 \%$. Identification of strain SFB has further expanded the upper $\mathrm{pH}$ limit at which microbial Fe(III) reduction has been observed, as B. arsenicoselenatis, A. metalliredigens strain QYMF, and Anaerobranca sp. were not capable of growth at a pH of 11.0 (Blum et al. 1998; Gorlenko et al. 2004; Ye et al. 2004).

During the fermentation of fructose, strain SFB diverted $12.5 \%$ of reducing equivalents to the reduction of $\mathrm{Fe}(\mathrm{III})$, further oxidizing the fermentation product, lactate, to acetate and $\mathrm{CO}_{2}$. The utilization of Fe(III) as an electron sink is a common process employed by a variety of fermentative bacteria (Lovley 1987; Lovley et al. 2004). Although the incomplete oxidation of lactate coupled to $\mathrm{Fe}(\mathrm{III})$ reduction is energetically favorable (Eq. 2), strain SFB was unable to couple this metabolism to growth. However, biomass did not decrease, suggesting that a net metabolic advantage is derived from Fe(III) reduction. This may be achieved via the oxidation of $\mathrm{NAD}(\mathrm{P}) \mathrm{H}$ coupled to $\mathrm{Fe}(\mathrm{III})$ reduction during fermentation yielding a net gain in the generation of adenosine triphosphate similar to the strategy proposed for Clostridium beijerinckii (Dobbin et al. 1999). This metabolism not only has implications toward energetic maintenance of the microbial population but also the mineralization of organic matter and iron redox cycling in these saline, alkaline environments.

Respiratory and fermentative Fe(III) reduction would result in increased amounts of oxidized simple organic acids, which would then be available for oxidation by other respiratory metabolisms including respiratory metal reduction. Mixed fermentation and Fe(III) reduction may then occur simultaneous with respiratory $\mathrm{Fe}(\mathrm{III})$ reduction by a microbial community consisting of both fermentative and respiratory microorganisms. As strain SFB, B. arsenicoselenatis, A. metalliredigens strain QYMF, and Anaerobranca sp. are capable of respiratory $\mathrm{Fe}(\mathrm{III})$ reduction (Blum et al. 1998; Gorlenko et al. 2004; Ye et al. 2004), it would be expected that respiratory metal reduction is a metabolic process occurring in alkaline, saline environments. However, very little is known regarding iron biogeochemistry in these environments or the microorganisms associated with this metabolically catalyzed biogeochemical process.

\section{Environmental significance}

Natural alkaline, saline environments are similar to geologically recent soda lakes and were likely present in the late Archean era (Kempe and Degens 1985; Jones et al. 1998). Given the diverse nature of the microbial communities in these alkaline environments, Zavarzin (1993) has asserted that soda lakes were potentially the origin of microbial diversity. Recognition of strain SFB as well as other alkaliphilic Fe(III)-reducing bacteria in such environments further extends not only the genetic diversity but also the metabolic diversity of the microbial communities in these natural environments.

The isolation of an $\mathrm{Fe}(\mathrm{III})$-reducing bacterium from an alkaline salt flat of a soda lake indicates that microbially mediated Fe(III) reduction could play a significant role in soda lake biogeochemistry. Microbial reduction of a variety of solid-phase $\mathrm{Fe}(\mathrm{III})$ under alkaline conditions is possible. Gorlenko et al. (2004) documented the ability of $A$. californiensis to reduce a solid-phase $\mathrm{Fe}(\mathrm{III})$ oxide, hydrous ferric iron oxide. The variety of insoluble Fe(III) oxides that strain SFB is capable of reducing is currently unknown. Further biogeochemical studies are needed to characterize the form and availability of $\mathrm{Fe}$ (III) minerals for microbial $\mathrm{Fe}(\mathrm{III})$ reduction in saline, alkaline environments as well as the contribution of microbial Fe(III) reduction to soda lake biogeochemistry.

Acknowledgments - Research in the labs of JDC and LA on microbial iron redox cycling was supported by the Office of Science (BER), US Department of Energy, Grant no. DE-FG0207ER64390. Brent M. Peyton is thanked for sample collection, and John J Macauley and Michelle A. Klippel are thanked for initiating the enrichments. 


\section{References}

Blum JS, Bindi AB, Buzzelli J, Stolz JF, Oremland RS (1998) Bacillus arsenicoselenatis, $\mathrm{sp}$ nov, and Bacillus selenitireducens, sp nov: two haloalkaliphiles from Mono Lake, California that respire oxyanions of selenium and arsenic. Arch Microbiol 171(5):19-30

Boone DR, Liu YT, Zhao ZJ, Balkwill DL, Drake GR, Stevens TO, Aldrich HC (1995) Bacillus-Infernus sp.-nov, an Fe(III)reducing and $\mathrm{Mn}(\mathrm{IV})$-reducing anaerobic from the deep terrestrial subsurface. Int J Syst Bacteriol 45:441-448

Bowman JP, McCammon SA, Nichols DS, Skerratt JH, Rea SM, Nichols PD, McMeekin TA (1997) Shewanella gelidimarina sp. nov. and Shewanella frigidimarina sp. nov., novel Antarctic species with the ability to produce eicosapentaenoic acid (20:5 omega 3 ) and grow anaerobically by dissimilatory Fe(III) reduction. Int J Syst Bacteriol 4:1040-1047

Bruce RA, Achenbach LA, Coates JD (1999) Reduction of (per) chlorate by a novel organism isolated from paper mill waste. Environ Microbiol 1:319-329

Caccavo F, Lonergan DJ, Lovley DR, Davis M, Stolz JF, McInerney MJ (1994) Geobacter sulfurreducens sp. nov., a hydrogen- and acetate-oxidizing dissimilatory metal-reducing microorganism. Appl Environ Microbiol 60:3752-3759

Coates JD, Michaelidou U, Bruce RA, O'Connor SM, Crespi JN, Achenbach LA (1999) Ubiquity and diversity of dissimilatory (per)chlorate-reducing bacteria. Appl Envir Microbiol 65:5234-5241

Coates JD, Phillips EJP, Lonergan DJ, Jenter H, Lovley DR (1996) Isolation of Geobacter species from a variety of sedimentary environments. Appl Environ Microbiol 62:1531-1536

Cornell RM, Schwertmann U (2003) The iron oxides: structure, properties, reactions, occurrences and uses, 2nd edn. Wiley-VCH, Weinheim

Dobbin PS, Carter JP, San Juan CG-S, van Hobe M, Powell AK, Richardson D (1999) Dissimilatory Fe(III) reduction by Clostridium beijerinckii isolated from freshwater sediment using Fe(III) maltol enrichment. FEMS Microbiol Lett 176:131-138

Duckworth AW, Grant WD, Jones BE, van Steenbergen R (1996) Phylogenetic diversity of soda lake alkaliphiles. FEMS Microbiol Lett 19:181-191

Gorlenko V, Tsapin A, Namsaraev Z, Teal T, Tourova T, Engler D, Mielke R, Nealson K (2004) Anaerobranca californiensis sp nov., an anaerobic, alkalithermophilic, fermentative bacterium isolated from a hot spring on Mono Lake. Int J Syst Evol Microbiol 54:739-743

Hungate RE (1969) A roll tube method for cultivation of strict anaerobes. Methods Microbiol 3B:117-132

Jones BE, Grant WD, Duckworth AW, Owenson GG (1998) Microbial diversity of soda lakes. Extremophiles 2:191-200
Kanso S, Greene AC, Patel BKC (2002) Bacillus subterraneus sp. nov., an iron and manganese reducing bacterium from a deep subsurface Australian thermal aquifer. Int J Syst Evol Microbiol 52:869-874

Kashefi K, Lovley DR (2003) Extending the upper temperature limit for life. Science 301:934-934

Kempe S, Degens ET (1985) An early soda ocean. Chem Geol 53:95

Kusel K, Dorsch T, Acker G, Stackebrandt E (1999) Microbial reduction of $\mathrm{Fe}(\mathrm{III})$ in acidic sediments: isolation of $\mathrm{Aci}$ diphilium cryptum JF-5 capable of coupling the reduction of $\mathrm{Fe}(\mathrm{III})$ to the oxidation of glucose. Appl Environ Microbiol 65:3633-3640

Lovley DR (1987) Organic matter mineralization with the reduction of ferric iron: a review. Geomicrobiol J 5:375-399

Lovley DR, Holmes DE, Nevin KP (2004) Dissimilatory Fe(III) and Mn(IV) reduction. Adv Microb Phys 49:219-286

Lovley DR, Phillips EJP (1988) Novel mode of microbial energy metabolism: organic carbon oxidation coupled to dissimilatory reduction of iron or manganese. Appl Environ Microbiol 54:1472-1480

Ma Y, Zhang W, Xue Y, Zhou P, Ventosa A, Grant WD (2004) Bacterial diversity of the Inner Mongolian Baer Soda Lake as revealed by $16 \mathrm{~S}$ rRNA gene sequence analyses. Extremophiles 8:45-51

Nielsen P, Fritze D, Priest FG (1995) Phenetic diversity of alkaliphilic Bacillus strains: proposal for nine new species. Microbiol 141:1745-1761

Nielsen P, Rainey FA, Outtrup H, Priest FG, Fritze D (1994) Comparative $16 \mathrm{~S}$ rDNA sequence analysis of some alkaliphilic bacilli and the establishment of a sixth rRNA group within the Bacillus. FEMS Microbiol Lett 117:61-66

Roden EE, Lovley DR (1993) Dissimilatory Fe(III) reduction by the marine microorganism Desulfuromonas acetoxidans. Appl Environ Microbiol 59:734-742

Roh Y, Liu S, Li GS, Huang HS, Phelps TJ, Zhou JZ (2002) Isolation and characterization of metal-reducing Thermoanaerobacter strains from deep subsurface environments of the Piceance Basin, Colorado. Appl Environ Microbiol 68:6013-6020

Weber KA, Achenbach LA, Coates JD (2006) Microorganisms pumping iron: anaerobic microbial iron oxidation and reduction. Nat Rev Microbiol 4:752-764

Ye Q, Roh Y, Carroll SL, Blair B, Zhou JZ, Zhang CL, Fields M (2004) Alkaline anaerobic respiration: Isolation and characterization of a novel alkaliphilic and metal-reducing bacterium. Appl Environ Microbiol 70:5595-5602

Zavarzin GA (1993) Epicontinental soda lakes as probable relict biotopes of terrestrial biota formation. Microbiol 62:473-479 